ROCZNIKI KULTUROZNAWCZE

Tom/Vol. XII, numer/number $1 \quad-\quad 2021$

DOI: http://doi.org/10.18290/rkult21121-5

JUAN ALEJANDRO CHINDOY CHINDOY

\title{
DANCING AS ENVIRONMENTAL AESTHETICS FROM INDIGENOUS AMERICA
}

\section{THE CONTINUITY OF NATURE AND SPIRIT IN INDIGENOUS AMERICA}

Before explaining the ideas of nature and the spirit in indigenous America it might be useful to recall briefly the most prominent conceptions of nature in western culture. Following Robert George Collingwood, the most dominant ideas of nature and the spirit come from the Greeks, the Renaissance, and the influence of biology in philosophy in the eighteenth century. The Greeks characterized nature as an orderly alive realm in which human life participated. Central to this Greek idea is that all bodies have a dynamic power, a self-moving force, operating constantly but not randomly. In the Greek mind this meant that nature is an intelligent organism, in many respects like the human organism, and not a blind matter. The study of nature thus became also a study of the human spirit, as there is a correlation between human intelligence and the natural world (Collingwood 2019, 18).

Collingwood describes that the second dominant idea of nature in western culture springs from the XVI and XVII centuries. This new idea of nature is an anthesis of the Greek version, inasmuch as it deprives nature from its vitality, negating it to be an organism, and assuming it to be a machine, in inert matter, an object to be dominated if understood mathematically. Collinwood is careful to explain that the modern idea of nature does not imply that Nature functioned whimsically. Like the Greeks, the moderns maintain that the laws of nature suggest order in the cosmos. But they did not think this order came from nature itself, but from an external force, from an all-

Dr. Juan Alejandro Chindoy Chindoy — Caldas University, Colombia; e-mail: juan.chindoy@ ucaldas.edu.co; ORCID: https://orcid.org/0000-0003-1165-0933. 
watching and powerful architect. In this second idea of nature, movement springs from external forces, manipulated from external operators.

A third idea of nature comes from the idea of process, evolution and development, which, in western culture emerged at the middle of the 18th century and became profound in the 19th century. Both the history of human institutions and of the incipient biology of the 19th century indicated that the essential features of the living organism were indeed transient modes of being. The fixity of human conceptualizations of the natural environment were attempts to capture the temporal pulses of existence, the actualizations of the becoming, but never its final essences (CollingwoOd 2019, 19-30).

The idea of nature in indigenous America is similar to the characterization that Collinwood had made of the Greek notion of nature. Indigenous Americans seen Nature as an organism whose vitality deserved to be honored through rituals, myths and celebrations, and political action (ToELKen 2003; see also: Toelken 1992). This means that the human spirit participates in the vital process of Nature. It is neither that Nature's functionality depended of human will nor that human willingness dominated all the forces of nature. It is that human action and the natural forces have the power to modify some of the vital processes of nature, which in turn affects both human spirit and the natural environment. For example, the human imagination to construct a house in a natural environment affects the harmony of the environment, as the human activity modifies the natural process. From a native perspective, this means that a detached sense of imagination, a sense of imagination which prioritizes human needs of shelter over the harmonious existence of other living creatures dramatically affects the harmony of nature. On the contrary, an embodied sense of imagination that takes into account the effects of human activity over other natural species operates in harmony with nature. An embodied imagination synthesizes the natural harmony. When this creative process of synthesis becomes a narrative, a story to be transmitted actively from one generation to the next, it becomes a myth. And when it is enacted, it becomes a ritual or a celebration. Thus, in the indigenous America, myth and ritual symbolize Nature's living process of transformation with aesthetic significance which scholars have well documented (EATON 1999, 12).

Scholars on native Latin America thinking agree to say that the clearest manifestation of the strong relation that indigenous groups have with nature comes from the different words used by native groups to refer to Nature, reserving a different word to refer to the physical space which is the mark of 
property (GALEAno 2018,64). One of the prominent examples comes from the colonial writings of Garcilaso de la Vega, the Inca who describes that the Incas used to called Pachacámac to the divine principle from which all existence comes. Garcilaso explains that Pacha means "the universe," and Cámac, a present participle of the verb cama, which means "anima" (GARCILASO DE LA Vega 1609, 7). The Spanish word for anima here is equivalent to the Greek word Tales used $\check{\mu} \mu \varphi v \chi o ́ v$ to describe that the world is "alive" (Collingwood 2019, 54). When an Inca person speaks of Pachacámac, it means that she is condensing in this concept the meaning of life, of fertility, and the growth of existence, which is beyond the physical space. Pachacámac is neither a representation, a picture of a physical environment, nor an inert matter. She is a living organism, a higher being, who becomes part of human life in rituals, myths, celebrations. And serves as a philosophical explanation of the principle of life, of the possibilities of existence, providing meaning to human life. Philosophically, Pachacámac is a postulate which orients all significant relations that humans are called to have with the rest of the world; the inga people in the southwest of Colombia, descendants of the Inca empire, keep alive this philosophical principle. They, like their neighbors, the Kamëntšás, enjoy annually a dancing ceremony in which the forces of Nature (called Pachamama in the language of the Ingas and Tsbatsanamamá in the language of the Kamëntšás), are enacted (CHINDOY 2020, 45-52).

Like in south America, indigenous communities in north America emphasize the special significance of Nature for human existence (JAHNER 1992, 193203). Native American philosophy comes from a critical reflection upon Land, understood not as a physical space to be occupied, but as the source of the possibilities of existence, as the source of all beings (Hultkrantz, 9-44). Thus, not only myths and rituals of origins, ceremonies of renewal and celebrations of life and death come from the value of the forces of nature, but also political, ethical, and social manifestations depend on an adequate appreciation of the symbolic significance of nature (ENGLE 2018, 105).

The symbolic significance of nature, the philosophical view that the principle of continuity between humans and the natural environment should be honored and taken from the heart has united indigenous peoples across the Americas (Muenlebach 2001, 415-448). In as much as the Inca culture influenced most of the native cultures of the Andes in south America, it is safe to indicate that Latin American references to Mother Earth keep alive this philosophical sense of Nature and takes different forms in aesthetics as well as in legal and social philosophy. Since the 70s, efforts to consolidate this philosophical view were common in social movements, articulating 
political demands for the recognition of native's special relation with the natural environment (CHADwicK 1998, 236-255). Gradually, these political demands echoed internationally. Not only the United Nations has recognized the value of the philosophical idea of the symbolic meaning of the land for the indigenous peoples, but also countries like Bolivia, Ecuador, and at times Colombia, have incorporated this symbolic sense of the Nature in their recent legal histories (LAMPREA MONTEALEGRE 2019, 27). This means that the idea of the continuity between human action and the land has been long debated and cherished among native communities in the Americas, at least long before the debates on environmental aesthetics took seriously the pursuit of harmony between humanity and the rest of the environment.

The different expressions to refer to Nature indicate two different senses of relating with it, one deeper than the other. When nature is referred to as Mother Earth, it means that humans are called to hold a relationship of care, wonder, respect, and reciprocity with the rest of the natural environment (Momaday 1997, 42-49). It also means that instead of a radical distinction between the human action and the natural environment, there operates a principle of continuity; instead of thinking that natural resources are only at human disposal, the principle of continuity requires thinking that natural resources are fundamental part of natural harmony, of the equilibrium of different existing organisms. Humans here participate in the flow of existence.

\section{DANCING AS THE AESTHETIC EMBODIMENT OF THE CONTINUITY}

Environmental aesthetics emerged historically as a reaction to the kind of philosophy of art that had strongly emphasized on the meaning of art instead of the meaning of aesthetic experiences (EATON 1999, 12-13). In limiting arts to the representation or enactment of the beautiful created mostly from the spirit of an individual, the philosophy of art has limited our comprehension of the aesthetic experiences which come from dancing (HANNA [et al.] 1979). Though in western philosophy Immanuel Kant and Edmund Burke are taken to be precursors of environmental aesthetics for their characterizations of the vast, wild, and sublime aspects of Nature as aesthetically meaningful, they did not include dancing as a form in which the beautiful reached completion. They appreciated the sublime forces of nature but pretend those forces to be outside of aesthetical enactment. Additionally, clouded with racism as some, 
like Hegel, were, there was not appreciation of the aesthetic experiences of dancing coming from non-European cultures (HALL 2017, 43-61). The most prominent developments of environmental aestheticians have come to the fore in the last few decades, along with the environmental revolution of the 60s (Kennedy, Sell, and ZuBe 1988, 35-51). Unlike the philosophy of art that emphasizes the creative individual, environmental aesthetics centers on the collective kinds of beautiful experiences that go beyond the arts. From the perspective of environmental aesthetics, not only artifacts, historical objects or well-recognized galleries give a sense of the beauty, but also, daily life objects provide meaningful aesthetic experiences. Daily events reach an aesthetic experience when it affects deeply on a human community. For example, the lighting at night before a storm becomes of an aesthetic experience for an agricultural community of people wherein it is taken to be symbol of nature, a form of expression of the powers of nature.

Although he is well known for having excluded dance as a form of art, Hegel is well known for his idea that truth meets in form with the beautiful in the arts. He wrote that the beautiful is "spirituality embodied in form" (HEGEL 2006, 27). In other words, he meant to say that the beautiful in art, whether it is expressed in architecture, sculpture, or poetry, is the formal manifestation of truth. We had to wait until John Dewey's view of art to understand that dancing is also a form, an intensified form of experience. With Dewey's ideas of art, dancing, which in native cultures never lost its commual aesthetic dimension, restored the aesthetic dignity in western philosophy (DEwey 1934, 5-6). From Dewey's perspective, experience is the result of the interaction of a living creature with its enviroment. The most intensified experiences that result from this interaction make the realm of the aesthetic experiences. They are embodied experiences, creating meaning for a human community, not for a detached individual.

Using Dewey's characterization of bodily aesthetics, one can interpret native dancing as kind of aesthetic experience, one that takes on the dramas of existence. This is so because all meaningful native aesthetic experiences are enactments of the core belief about the relations of harmony that humans seek to establish in the universe. In a native dancing, thus, the human strivings, sufferings, hopes, and dreams, correlate with the forces of existence, with the process of life and death of living organisms. Ritual and myth are part of dancing, inasmuch as they vitalize the harmony of a community. To use Dewey's words, dancing is an embodiment of the most intense forms of the aesthetic experiences. 
One might wonder why native dancing expresses the most refined enviromental aesthetic, given the fact that native dancing has traditionally been characterized as part of myth, ritual, or with a religious experience (see, for example, CASSIRER 1995; Eliade 1963). One clear reason to indicate that native dancing represents the most intense form of aesthetic enviroment comes from its attempts to fully grasp the meanign of human interaction with the forces of nature. Native dancing takes into account the forces of nature and its effects on the spirit of a given community (SOLOMON 2000, 257-280). It speaks of a kind of vitalist metaphysics, one which affirms that the world is not yet finished but, in a process, wherein our collective actions might give new shape to existence. In so doing, it abhors to glorify the deeds of an individual. While in a dancing ceremony some might be dancing mechanically, somehow concerned about how others may be watching, the spirit of the dance rests in its capacity to absorb everyone, with an aura of fascination at the musical rythms of flutes, drums, harmonicas, or sayings of rituals. This collective power operates almost unconsciously, making people be engaged in an aesthetic experience before thinking about it (DEWEY 1934, 30-32). It is not that thinking is utterly suspeded, but that the dancing does not make anyone to be a cold spectator. Native dancing thus represents best the organic spirit of Nature. In a native dancing the forces of human, the powers of human spirit, meet the powers of nature (PRAET 2009, 737-754).

Native dancing is not a merely a representation of the dramas of existence. It is also an act of creation in which time and space acquire a deep meaning (VAN GiJSEghem and Whalen 2017). It is as if the present stopped the flow of time, or as if the space of dance would make it sacred. This is so because dancing is an act of participation with Nature, much like a way of honoring its vital forces. With it, time and place become sacred. The realm of the possibilities of life become actual, nurturing the collective sense of the community. Unlike the creative individual whose inspiration sparks from its inner, deeper self-awareness, the creative impulse of the community in the dancing comes from an imagined community, a group of ancestors who had participated in shaping the beautiful and which still inspire the community of the present (Toelken 2003, 15). This process of co-participation is not transient, ephemeral, but as Kant puts it, is an example of the purposiveness without a specific purpose.

Dancing intensifies the flow of time. Although it could last one day, a native dancing is a celebration which brings back the times of the ancestors. By recalling their deeds, their rituals, their concerns and fears, the memory 
of the ancestors is renewed. Dancing like the ancestors used to do it signifies at the same time dancing with them. Consequently, the past meets the present, fusing its energy into the present; it is as if the present revealed its roots. Put it in another way, dancing actualizes the possibilities of the flow of time. It makes us aware of the possibility of transcending the present without denying it or escaping from it. It is an expression of inner time without negating its external force. Likewise, it is an expression of inner space within outer space.

This embodiment of life's hardships, of its challenges which thwart the vital impulses of existence, crystalizes the flow of human life. Taking on the blind forces of nature, dancing does not deny the reality of evil, of the ugliness, of that which represents disharmony (CHINDOY 2020, 57-59). Neither it does aestheticize evil, which is to say, it does not suppose that the ugly is a disguised form of the beautiful. On the contrary, it takes the ugliness of life to be real, just as the beauty. The only difference is that the recognition of the existence of evil does not imply that we should be thankful for it. It rather implies that we are called to continue to renew our roots so as to participate in the maintenance of the balance of nature.

\section{BIBLIOGRAPHY}

AleXANDER, Hartley Burr. 1953. The World's Rim: Great Mysteries of the North American Indians. Lincoln, NE: University of Nebraska Press.

CASsiRer, Ernst. 1995. The Philosophy of Symbolic Forms, Volume II: Mythical Thinking. New Haven and London: Yale University Press.

ChaDwick, Allen. 1998. "Blood as Narrative/Narrative as Blood: Declaring a Fourth World." Narrative 6, no. 3: 236-255. https://www.jstor.org/stable/20107155.

Chindoy, Juan A. 2020. A Decolonial Philosophy of Indigenous Colombia: Time, Beauty, and Spirit in Kamëntšá Culture. London: Rowman \& Littlefield Publishers.

Collingwood, Robin George. 2019. Idea de la Naturaleza. Translated by Eugenio Imaz. México: Fondo de Cultura Económica.

Dewey, John. 1934. Art as Experience. New York: Penguin Group.

Eaton, Marcia Muelder. 1999. "Kantian and Contextual Beauty." The Journal of Aesthetics and Art Criticism 11-15. https://www.jstor.org/stable/432059.

Eliade, Mircea. 1963. Myth and Reality. Long Grove, IL: Waveland.

Engle, Karen. 2018. El Desarrollo Indígena, Una Promesa Esquiva. Bogotá: Siglo del Hombre Editores.

Galeano, Eduardo. 2018. Las Venas Abiertas de América Latina. México: Siglo XXI Editores.

Garcilaso de la Vega, Inca. 1609. Comentarios Reales de los Incas: Primera Parte. Lisboa. 
HaLl, Joshua M. 2017. "St. Vitus's Women of Color: Dancing with Hegel, Comparative and Continental Philosophy." Comparative and Continental Philosophy 9, no. 1: 43-61.

HannA, J. Lynne [et al.]. 1979. "Movements Toward Understanding Humans Through the Anthropological Study of Dance [and Comments, and Reply]." Current Anthropology 20, no. 2: 313-33. www.jstor.org/stable/2741929.

Hegel, Georg Wilhelm Friedrich. 2006. The Philosophy of Art. New York: Barnes \& Noble.

Hultkrantz, Åke. 1979. The Religions of the American Indians. Translated by Monica Setterwall. Berkeley: University of California Press.

JAHNER, Elaine. 1992. "The Spiritual Landscape." In D.M. Dooling and Paul JordAn-SMith. I Become Part of It: Sacred Dimensions in Native American Life. New York: Haper Collins.

Kennedy, Christina B., James L. Sell, and Ervin H. Zube. 1988. "Landscape Aesthetics and Geography." Environmental Review 12, no. 3: 35-51. https://www.jstor.org/stable/ 3984284.

Lamprea Montealegre, Everaldo. 2019. El Derecho de la Naturaleza: Una Aproximación Interdisciplinaria a los Estudios Ambientales. Bogotá: Siglo del Hombre Editores.

Momaday, N. Scott. 1997. The Man Made of Words. New York: St. Martin's Griffin Press.

Muenlebach, Andrea. 2001. “'Making Place' at the United Nations: Indigenous Cultural Politics at the U.N. Working Group on Indigenous Populations.” Cultural Antropology 16, no. 3: 415-448.

Praet, Istvan. "Shamanism and Ritual in South America: An Inquiry into Amerindian ShapeShiting." The Journal of the Royal Anthropological Institute 15 (2009), no. 4: 737-754. www.jstor.org/stable/40541752.

Solomon, Thomas. 2000. "Dueling Landscapes: Singing Places and Identities in Highland Bolivia." Ethnomusicology 44, no. 2: 257-280. www.jstor.org/stable/852532.

Toelken, Barre. 2003. "Cultural Patterns in Native American Folklore: An Introduction.” In Barre Toelken. Anguish Of Snails: Native American Folklore in the West, 9-24. Logan, UT: University Press of Colorado.

Toelken, Barre. 1992. "The Demand of Harmony." In D.M. Dooling and Paul Jordan-Smith. I Become Part of It: Sacred Dimensions in Native American Life, 59-71. New York: Haper Collins.

Van Gijseghem, Hendrik, and Verity H. Whalen. 2017. "Mining, Ritual, and Social Memory: An Exploration of Toponymy in the Ica Valley, Peru." In Rituals of the Past: Prehispanic and Colonial Case Studies in Andean Archaeology, edited by Silvana Rosenfeld and Stefanie L. Bautista. Boulder, 267-294. Colorado.: University Press of Colorado.

\section{DANCING AS ENVIRONMENTAL AESTHETICS FROM INDIGENOUS AMERICA}

\section{S u m mary}

Contemporary studies on environmental aesthetics emphasize the relationship of continuity between nature and human action. Most of these critical approaches suggest that the emphasis on the continuity of nature with humanity implies a change of attitude to the natural environment, meaning that we should move away from the exploitation of the natural environment and focus on its preservation and conservation. In the two sections of this paper, it is argued that the idea for the continuity of humans with the natural environment has for a long time been a core philosophical belief in indigenous America, the oldest aesthetic manifestation of which has been 
expressed in the forms of dancing. The first section is dedicated to the idea of continuity in indigenous America, emphasizing on the concepts of Mother Nature and Human Spirit. The second part shows that native dancing embodies aesthetically the idea of continuity of human action and the natural environment.

Keywords: native dancing; environmental aesthetics; philosophy of dance; indigenous American dance.

\section{TANIEC JAKO ESTETYKA ŚRODOWISKOWA Z RDZENNEJ AMERYKI \\ Streszczenie}

Współczesne badania estetyki środowiskowej podkreślają ciągłość między naturą a ludzkim działaniem. Większość z tych podejść sugeruje, że nacisk na ciągłość przyrody z ludzkością implikuje zmianę podejścia do środowiska naturalnego, co oznacza, że powinniśmy odejść od eksploatacji środowiska naturalnego i skupić się na jego ochronie i zachowaniu. W dwóch częściach tego artykułu argumentuje się, że idea ciągłości człowieka ze środowiskiem naturalnym była przez długi czas rodzimą wiarą filozoficzną rdzennej Ameryki, której najstarszą estetyczną manifestacją był taniec. Pierwsza część poświęcona jest idei ciągłości w rdzennej Ameryce, z położeniem nacisku na koncepcje Matki Natury i Ducha Człowieka. Druga część pokazuje, że rodzimy taniec uosabia estetycznie ideę ciągłości ludzkiego działania i środowiska naturalnego.

Przełoży Stanisław Sarek

Slowa kluczowe: taniec rodzimy; estetyka środowiskowa; filozofia tańca; rdzenny taniec amerykański. 